\title{
Development of the Geop-Pain questionnaire for multidisciplinary assessment of pain sensitivity
}

\author{
Sung-Hwan Cho, Su-Hwan Ko, Mi-Soon Lee, Bon-Sung Koo, \\ Joon-Ho Lee, Sang-Hyun Kim, Won Seok Chae, Hee Cheol Jin, \\ Jeong Seok Lee, and Yong-Ik Kim \\ Department of Anesthesiology and Pain Medicine, Soonchunhyang University Bucheon Hospital, Bucheon, Korea
}

\begin{abstract}
Background: To assess the multidisciplinary aspects of pain, various self-rating questionnaires have been developed, but there have not been sufficient relevant studies on this topic in South Korea. The aim of this study was to develop a new pain sensitivity-related questionnaire in the Korean language that would be simple and would well reflect Koreans' senses.

Methods: A new pain assessment questionnaire was developed through a pre-survey on "geop", which is the Korean word expressing fear, anxiety, or catastrophizing. We named the new assessment questionnaire the Geop-Pain Questionnaire (GPQ). The GPQ was composed of 15 items divided into three categories and rated on a 5-point scale. As a preliminary study, internal consistency and test-retest reliability analyses were conducted. Subsequently, 109 individuals completed the GPQ along with three pain-related questionnaires translated into Korean (Pain Sensitivity Questionnaire [PSQ], Pain Anxiety Symptoms Scale [PASS], and Pain Catastrophizing Scale [PCS]), and the correlations were analyzed.

Results: All items in the GPQ showed appropriate internal consistency, and the test-retest reliability analysis showed no statistically significant differences. The correlations between the GPQ and the existing questionnaires revealed that the GPQ scores had mid-positive correlations with the PSQ scores and strong positive correlations with the PASS and PCS scores.

Conclusions: This study attempted to develop a questionnaire assessing pain sensitivity multidimensionally using the Korean word geop for the first time. The self-rating GPQ showed high correlations with the existing questionnaires and demonstrated potential to be utilized as a pain prediction index in clinical practice.
\end{abstract}

Key Words: Anxiety, Catastrophization, Korean language, Multidisciplinary, Surveys and questionnaires.

Corresponding author: Sung-Hwan Cho, M.D., Ph.D.

Department of Anesthesiology and Pain Medicine, Soonchunhyang University Bucheon Hospital, 170, Jomaru-ro, Wonmi-gu, Bucheon 14584, Korea

Tel: 82-32-621-5323, Fax: 82-32-621-5322

E-mail: singaring@schmc.ac.kr

This is a thesis for a Doctor's degree by Sung-Hwan Cho.

Received: January 15, 2016.

Revised: March 31, 2016 (1st); May 27, 2016 (2nd).

Accepted: May 31, 2016.

Korean J Anesthesiol 2016 October 69(5): 492-505

http://dx.doi.org/10.4097/kjae.2016.69.5.492

\section{Introduction}

Pain assessment is very important for the accurate assessment of the conditions of patients with pain, as well as for their proper treatment. Pain, however, is a sensory and emotionally unpleasant subjective experience [1] and, in addition to simple tissue damage, has associations with various elements, including the patient's personal emotions, cultural background, past experiences, and socioeconomic environment. Thus, it is difficult to determine the criteria that can be used for definitively assessing pain. If a patient's level of pain sensitivity can be determined, then, based on this sensitivity level, the degree of pain that will

(c) This is an open-access article distributed under the terms of the Creative Commons Attribution Non-Commercial License (http://creativecommons.org/ licenses/by-nc/4.0/), which permits unrestricted non-commercial use, distribution, and reproduction in any medium, provided the original work is properly cited. 
be felt by the patient during surgery can be predicted prior to the surgery and an appropriate strategy for individual pain control will be possible. Additionally, this knowledge will be very helpful in the treatment of patients with chronic pain.

In pursuit of methods of pain assessment that will accurately reflect its complex characteristics, many studies have been performed to predict the level of pain sensitivity or to develop questionnaire surveys related to pain, but no significant achievements have been accomplished. Along with the continuous conduct of experimental studies measuring the level of sensitivity and diversity of individuals through the delivery of a pain stimulus $[2,3]$, the development of self-rating questionnaires is continuously being attempted [4-7]. Questionnaire surveys are one of the methods of assessing the pain felt by an individual in multidimensional aspects, and these have been diversely conducted since the first administration of a survey using the McGill Pain Questionnaire (MPQ), which assesses the intensity of pain. Multidimensional questionnaires of this type include the Pain Sensitivity Questionnaire (PSQ) [6], Pain Catastrophizing Scale, (PCS) [5], Pain Anxiety Symptoms Scale (PASS) [8], and Fear-of-Pain Questionnaire (FOPQ) [9], among others.

Compared to the international research, however, the relevant studies that have been performed in South Korea have been far from diverse, and in particular, multidimensional questionnaire surveys useful in the assessment of various types of neuropathic pain or other chronic diseases have not been widely conducted. The reasons for this are as follows. First, there is no existing Korean questionnaire that appropriately assesses the subjective thinking and feelings of the Korean patients. As with the MPQ, PCS, and PSQ, most of the questionnaires that are currently in use in South Korea were developed overseas and began to be employed after undergoing translation and certification processes [10,11], but South Koreans' social, economic, and cultural environments are fundamentally different from those found overseas. The second reason is the nature of the South Korean healthcare environment. Visual and objective tests such as ultrasound or magnetic resonance imaging (MRI) are preferred to subjective questionnaire surveys, which are unfamiliar in the South Korean healthcare environment, in which the treatment hours are not sufficient. Furthermore, as the patients are reluctant to provide responses to the questionnaire items, and many of the patients with chronic pain are elderly, there are obstacles, such as difficulty in conveying the contents of the questionnaire items. Therefore, there is a need to develop a questionnaire that can be administered simply, completed in a short time, consist of accessible items, and has a strong association with pain.

The pain questionnaires suggested above utilize terms such as fear, anxiety, and catastrophizing, but South Koreans commonly use the word "geop" when they recall the pain-related term. The word geop means fearful heart or psychological tendency, and its synonyms include horror, fear, fright, hesitation. That is, the meaning of geop is thought to be similar to fear, anxiety, avoidance, catastrophizing. Additionally, South Koreans are believed to have a high understanding of the dictionary meaning and concept of geop.

Therefore, this study aimed to develop a multidimensional questionnaire that can predict the level of a patient's pain sensitivity and that is easy to understand and well reflects South Koreans' feelings and emotions, instead of using an existing questionnaire that was developed overseas and utilized after going through translation and certification processes. In addition, the correlation between the level of geop and the occurrence of pain was investigated.

\section{Materials and Methods}

This study was approved by the Institutional Review Board. It was conducted targeting patients and their caregivers aged older than 20 years who visited a hospital. The study subjects were volunteers with sufficient knowledge of Korean, with no restrictions in filling out the questionnaire, with the ability to voluntarily communicate and seamlessly express what they want to express, and with no special disease. In the pre-survey for questionnaire item development, there were 80 volunteer participants; the preliminary study for verifying the validity of the questionnaire targeted 40 volunteers; and the main study was conducted with 120 volunteer participants. Prior to the surveys, it was sufficiently explained to the study subjects that the aim of the study was to investigate individuals' thoughts and feelings on the association between geop and pain. Participants were instructed to ask questions if they encountered questionnaire items that were difficult to understand while filling out the GPQ.

\section{Pre-survey}

The purpose of this study was to develop a questionnaire on the association between geop and pain using the Korean word geop for the first time. Thus, initial items relating to geop were created, and an initial survey was performed to organize the concept of geop. After confirming that the 80 study participants understood the concept of geop, they were asked to write about the situations in which they most strongly experienced geop.

\section{Development of the Geop-Pain questionnaire (GPQ)}

Referring to the data collected from the pre-survey as well as the existing questionnaires, a preliminary questionnaire reflecting various factors related to pain was created. The questionnaire was divided into three dimensions (sense, experience, and "other"), with the other dimension consisting of catastrophizing and so- 
cioeconomic environmental factors. Each dimension included five items, and consequently, the questionnaire had a total of 15 items. Items 1 to 5 , belonging to the sense dimension for geop, were related to the differences in the senses (e.g., vision, hearing); items 6 to 10 , belonging to the experience dimension for geop, were related to geop after experiencing fear or pain; and items 11 to 15, belonging to other dimension for geop, were items in which exaggerated thinking, a victim mentality, a sense of alienation, and cost were associated with geop. For each item, unrealistic elements were eliminated from the geop-inducing situations expressed by the participants in the first survey, and only the episodes that were both associated with pain and commonly occur in everyday life were used. After completion of the questionnaire, it was reviewed by two pain specialists. The scores that were given as responses to the questionnaire items ranged from 1 (not at all) to 5 (very severe).

\section{Internal consistency and test-retest reliability analyses}

The first preliminary study was conducted targeting 40 volunteers, and after three weeks, the second preliminary study was conducted using the same questionnaire. Excluding three participants who could not be involved in the second preliminary study and two participants whose data were partially omitted, the data of 35 participants were utilized for analyses. Using the data gathered from the two preliminary studies, to determine the degree of homogeneity among the questionnaire items belonging to the same dimension (sense, experience, other), the validity of the items was analyzed, and to determine if the respondents' answers to the questionnaire items were consistent, the reliability of the answers was analyzed. For the test-retest reliability, the first and second preliminary study data were compared. After the preliminary studies, the final questionnaire was named the "Geop-Pain Questionnaire (GPQ)" (Appendix 1). In addition, to investigate the basic characteristics of the study participants and their thoughts on geop and pain, a questionnaire for the general measurement of geop (Appendix 2) including items on sex, age, pain treatment experience, level of geop, and degree of Geop-Pain association was administered during the preliminary studies and the main study, along with the GPQ. In the questionnaire, the participants were asked to express the level of geop they believed they had (level of self-rating geop) and whether they thought geop was associated with pain (GeopPain association) in numbers ranging from 0 to 100 .

\section{Main study}

The purpose of the main study was to verify whether the GPQ could be used clinically. Targeting 120 volunteers, the GPQ was administered along with the PSQ, PASS-20, and PCS, and following the exclusion of 11 respondents with partially omitted records in their completed questionnaires, the data of 109 individuals were finally analyzed. To identify the correlations between the GPQ and the three existing questionnaires, first, the correlations between the total score on the GPQ and those on the three existing questionnaires were analyzed. Additionally, the correlations of the three dimensions of the GPQ (sense, experience, and other) with the PSQ, PASS-20, and PCS were analyzed. Moreover, the correlations between the GPQ score with the level of self-rated geop and the Geop-Pain association score were analyzed.

\section{Statistical analysis}

Statistical analyses were performed using SPSS (Windows ver. 14.0, SPSS Inc., Chicago, IL, USA). For the continuous variable, mean \pm standard deviation was used, and for the categorical variables, frequency and percentage (\%) were utilized. Internal consistency (IC) was used to verify the validity of the items, and Cronbach's alpha was utilized as an index for reliability. The IC was assessed to be appropriate if it was higher than 0.3 , and Cronbach's alpha, if it was higher than 0.7. The test-retest reliability was analyzed using the paired t-test. Based on the data obtained from the main study, factor analysis was performed to determine whether each item in the GPQ was well distributed to the three dimensions. Using principal component analysis (PCA) applying varimax rotation, the dimensions were constructed by binding the items with higher factor loading. In addition, the variances explained by each dimension were calculated. To analyze the correlations with the scores in the three existing questionnaires, Spearman's rank correlation was employed. For the correlations of the GPQ score with the level of self-rated geop and the Geop-Pain association score, the multiple linear regression model was applied, and adjusting the age, sex, and pain treatment experience, the regression coefficients were estimated. As the range of the score of each dimension in the GPQ is different from that of the total score, using the sizes of the standardized coefficient beta, their linear relationships with the scores of the three pain questionnaires were compared. All statistical analysis results were determined to be significant when $\mathrm{P}<0.05$.

\section{Results}

The data that were collected from the first survey for questionnaire item development were classified by type (Table 1). The general characteristics of the participants, the time required for accomplishing the questionnaire, the level of geop, and the Geop-Pain association are presented in Table 2. The proportion of males was greater than that of females, and the 20-30-yearold age group was the largest. In the preliminary and main stud- 
ies, $22(62.9 \%)$ and $80(73.4 \%)$ respondents, respectively, had an experience of pain treatment. The mean self-rated geop scores were $58.3 \pm 20.2$ and $57.4 \pm 19.9$, respectively; the standard deviation was high, about 19-20; and the range of the self-rated geop score was 35-80, showing that the scores were widely distributed. For the Geop-Pain association, the scores were $66.4 \pm$ 23.6 and $63.1 \pm 23.9$, respectively, indicating that the scores were widely distributed between 40 and 80 , with a large standard deviation, as with the level of self-rated geop score. The time required for accomplishing the questionnaire was almost the same in both cases $(5.9 \pm 4.2$ and $5.6 \pm 3.8$ minutes, respectively), and the mean of the values representing the respondent's understanding of the questionnaire items were $79.4 \pm 18.1$ and $80.8 \pm$ 17.0 , respectively.

In the analysis results regarding the IC of the GPQ using the data obtained from the preliminary study targeting 35 individu-

Table 1. Pre-survey for Geop

\begin{tabular}{lc}
\hline \multicolumn{1}{c}{ When are you scared the most severely? } & No. of participants \\
\hline When I receive surgery or treatment & 12 \\
When I walk alone on a dark road at night & 9 \\
Threatening situations & 8 \\
When I am persistently very sick & 7 \\
Burden of work & 7 \\
Experience of an accident & 6 \\
When I am in an enclosed or unfamiliar place & 6 \\
When I am at a high place & 5 \\
Amusement park rides & 5 \\
Fear of something new (when first exposed & 5 \\
to a new environment or situation) & \\
When I watch a horror movie & 3 \\
Fear of certain things & 2 \\
When I see a ghost or have a nightmare & 2 \\
Others & 3 \\
Total & 80 \\
\hline
\end{tabular}

als, Cronbach's alpha was higher than 0.7 in all three dimensions (sense, experience, and other), which was appropriate (Table 3). The reliability was also very high in all the dimensions and in the total score on the GPQ, showing that the preliminary questionnaire well reflected the respondent's consistent response. As the results of the test-retest in which the tests were given twice using the same questionnaire did not show a statistically significant difference (Table 4), the GPQ was evaluated to be an instrument that could obtain consistent responses. Therefore, without any amendments to the questionnaire items, the main study was conducted.

In the main study targeting 109 subjects, as a result of the

Table 3. Internal Consistency of Geop-Pain Questionnaire ( $\mathrm{N}=35)$

\begin{tabular}{crcc}
\hline $\begin{array}{c}\text { Subgroup } \\
\text { No. of item }\end{array}$ & Score & IC & Cronbach's $\alpha$ \\
\hline Sensitivity & $10.84 \pm 3.82$ & & 0.836 \\
1 & $2.73 \pm 0.98$ & 0.61 & \\
2 & $2.36 \pm 1.01$ & 0.70 & \\
3 & $1.91 \pm 0.90$ & 0.54 & \\
4 & $2.16 \pm 1.11$ & 0.70 & \\
5 & $1.69 \pm 0.91$ & 0.65 & \\
Experience & $10.59 \pm 3.67$ & & \\
6 & $2.06 \pm 1.03$ & 0.49 & \\
7 & $2.26 \pm 1.11$ & 0.61 & \\
8 & $2.21 \pm 1.03$ & 0.62 & \\
9 & $2.20 \pm 0.97$ & 0.55 & \\
10 & $1.86 \pm 0.89$ & 0.48 & \\
Other & $9.83 \pm 3.23$ & & \\
11 & $1.97 \pm 0.96$ & 0.56 & \\
12 & $1.69 \pm 0.93$ & 0.52 & \\
13 & $2.37 \pm 0.94$ & 0.52 & \\
14 & $1.81 \pm 0.80$ & 0.62 & \\
15 & $1.99 \pm 0.86$ & 0.45 & \\
Total score & $31.26 \pm 9.36$ & & \\
\hline
\end{tabular}

Data are expressed as means \pm SD. IC: Internal consistency.

Table 2. Characteristics of the Study Population

\begin{tabular}{lccc}
\hline \multicolumn{2}{c}{ Variables } & Preliminary study $(\mathrm{N}=35)$ & Main study (N=109) \\
\hline Sex & Male & $13(37.1)$ & $44(40.4)$ \\
& Female & $22(62.9)$ & $65(59.6)$ \\
Age (yr) & & $30.3 \pm 5.8$ & $30.3 \pm 6.5$ \\
Age group & 20 's & $19(54.3)$ & $63(57.8)$ \\
& 30's & $14(40)$ & $39(35.8)$ \\
& 40 's & $2(5.7)$ & $5(4.6)$ \\
Experience of pain treatment & & $0(0)$ & $2(1.8)$ \\
Self-rating on Geop & & $22(62.9)$ & $80(73.4)$ \\
Subjective rating on the relation of Geop and pain & $58.3 \pm 20.2$ & $57.4 \pm 19.9$ \\
Time-required complete survey (min) & $66.4 \pm 23.6$ & $63.1 \pm 23.9$ \\
Understanding of the questions & $5.9 \pm 4.2$ & $5.6 \pm 3.8$ \\
\hline
\end{tabular}

Data expressed as means \pm SD or numbers (\%) of patients. 
Table 4. Test-retest Reliability for Geop-Pain Questionnaire $(\mathrm{N}=35)$

\begin{tabular}{|c|c|c|c|c|}
\hline $\begin{array}{l}\text { Subgroup } \\
\text { No. of item }\end{array}$ & 1st score & 2nd score & Mean difference & $\mathrm{P}$ \\
\hline Sensitivity & $11.23 \pm 3.99$ & $10.46 \pm 3.66$ & 0.77 & 0.15 \\
\hline 1 & $2.80 \pm 1.02$ & $2.66 \pm 0.94$ & 0.14 & 0.34 \\
\hline 2 & $2.46 \pm 0.95$ & $2.26 \pm 1.07$ & 0.20 & 0.21 \\
\hline 3 & $2.11 \pm 0.87$ & $1.71 \pm 0.89$ & 0.40 & 0.17 \\
\hline 4 & $2.20 \pm 1.11$ & $2.11 \pm 1.13$ & 0.09 & 0.67 \\
\hline 5 & $1.66 \pm 0.94$ & $1.71 \pm 0.89$ & -0.06 & 0.66 \\
\hline Experience & $10.97 \pm 3.84$ & $10.20 \pm 3.51$ & 0.77 & 0.13 \\
\hline 6 & $2.11 \pm 1.08$ & $2.00 \pm 1.00$ & 0.11 & 0.55 \\
\hline 7 & $2.29 \pm 1.18$ & $2.23 \pm 1.06$ & 0.06 & 0.71 \\
\hline 8 & $2.40 \pm 1.14$ & $2.03 \pm 0.89$ & 0.37 & 0.06 \\
\hline 9 & $2.26 \pm 0.92$ & $2.14 \pm 1.03$ & 0.11 & 0.49 \\
\hline 10 & $1.91 \pm 0.95$ & $1.80 \pm 0.83$ & 0.11 & 0.46 \\
\hline Other & $10.03 \pm 3.13$ & $9.63 \pm 3.35$ & 0.40 & 0.40 \\
\hline 11 & $2.06 \pm 1.00$ & $1.89 \pm 0.93$ & 0.17 & 0.25 \\
\hline 12 & $1.69 \pm 0.99$ & $1.69 \pm 0.87$ & 0.00 & 1.00 \\
\hline 13 & $2.46 \pm 0.92$ & $2.29 \pm 0.96$ & 0.17 & 0.23 \\
\hline 14 & $1.83 \pm 0.82$ & $1.80 \pm 0.80$ & 0.03 & 0.86 \\
\hline 15 & $2.00 \pm 0.84$ & $1.97 \pm 0.89$ & 0.03 & 0.85 \\
\hline Total score & $32.23 \pm 9.63$ & $30.29 \pm 9.13$ & 1.94 & 0.09 \\
\hline
\end{tabular}

Data are expressed as means $\pm \mathrm{SD}$.

Table 5. Factor Analysis for Explained Variance and Factor Loading for the Measurement Variables

\begin{tabular}{ccc}
\hline Subgroup No. of item & Factor loadings & Variance explained (\%) \\
\hline Sensitivity & & 39 \\
1 & 0.82 & \\
2 & 0.84 & \\
3 & 0.77 & \\
4 & 0.81 & \\
5 & 0.80 & \\
Experience & & \\
6 & 0.70 & \\
7 & 0.81 & \\
8 & 0.82 & \\
9 & 0.86 & \\
10 & 0.67 & \\
Other & \\
11 & 0.81 & \\
12 & 0.70 & \\
13 & 0.67 & \\
14 & 0.81 & \\
15 & 0.79
\end{tabular}

factor analysis, it was confirmed that each item of the GPQ was well arranged in the three dimensions (Table 5). Between the PSQ score representing the level of pain sensitivity and the GPQ score of each dimension and the total GPQ score, there were statistically significant mid-positive correlations, ranging from 0.2 to 0.3 (sense, $r=0.296$; experience, $r=0.242$; other, $r=0.237$; total, $\mathrm{r}=0.294$ ). Among the three dimensions, the sense dimension had the strongest correlation with the PSQ (Fig 1, Table 6). Between the PASS-20 score investigating the association between anxiety and pain and the GPQ score of each dimension and the total GPQ score, there were statistically significant strong positive correlations, ranging from 0.55 to 0.65 (sense, $r=0.553$; experience, $r=0.625$; other, $r=0.587$; total, $r=0.647$ ). Among the three dimensions, the experience dimension had the strongest correlation with the PASS-20 (Table 6).

Between the PCS, which measures the degree of catastrophizing pain, and the GPQ score of each dimension and the total GPQ score, there were statistically significant strong positive correlations, ranging from 0.50 to 0.63 (sense, $r=0.502$; experience, $r=0.589$; other, $r=0.627$; total, $r=0.621$ ). Among the three dimensions, the other dimension, including catastrophizing and socioeconomic environments, had the strongest correlation with the PCS (Table 6). The scores of all three dimensions showed positive correlations with the self-rated geop score, and the standardized coefficients (beta) of all the dimensions were significant (Table 7). Likewise, the Geop-Pain association score showed statistically significant associations with the GPQ scores of the sense and experience dimensions and the total GPQ score, and the standardized coefficients were very large. Although the catastrophizing and external dimension had a positive correlation with Geop-Pain association, their relationship was not statistically significant $(\mathrm{P}=0.095)$ (Table 7). 

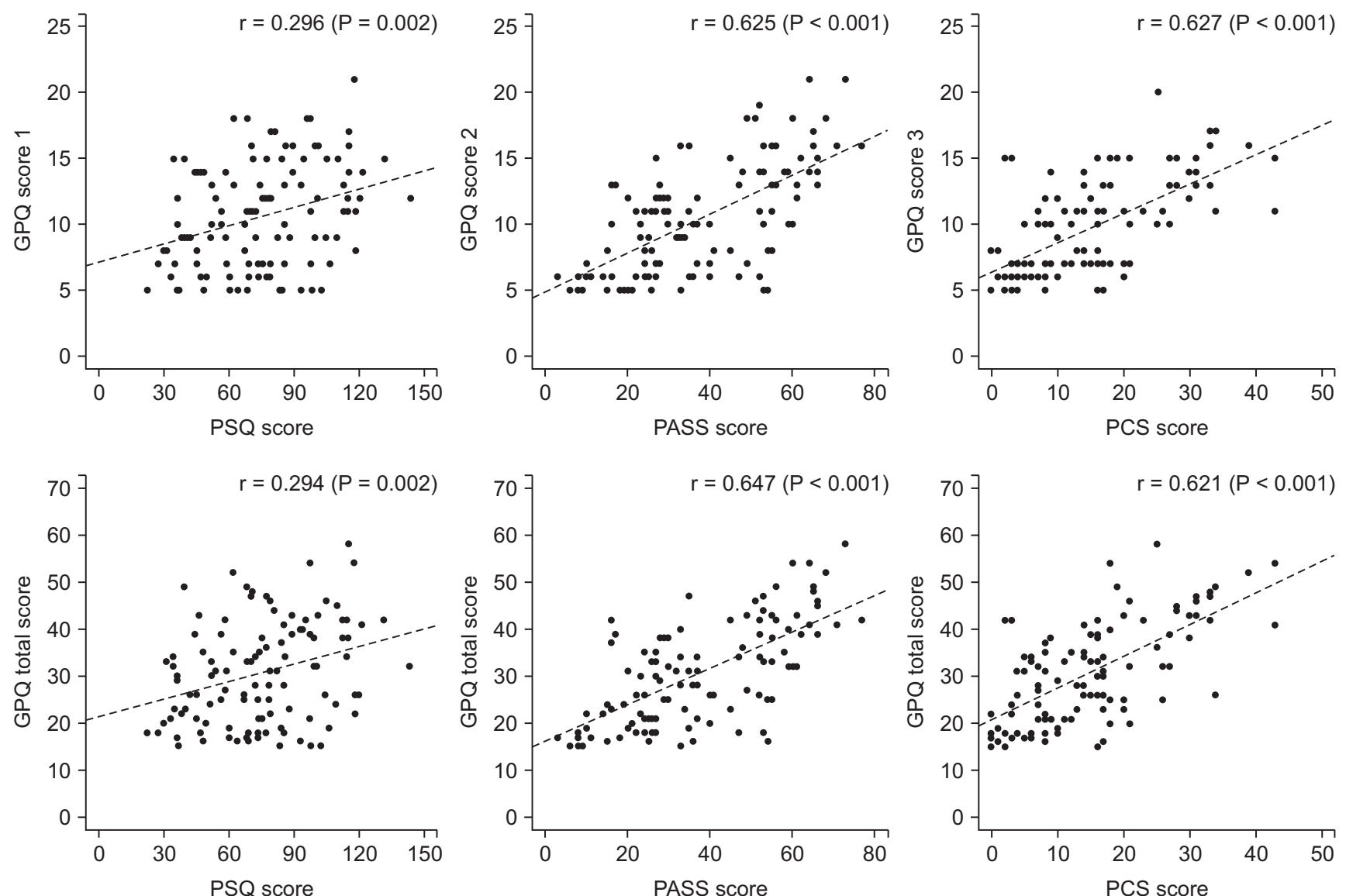

Fig. 1. Scatter Plot of GPQ Scores and the Other Questionnaires. Score 1: sensitivity, 2: experience, 3: other. GPQ: Geop-Pain Questionnaire, PSQ: Pain Sensitivity Questionnaire, PASS: Pain Anxiety Symptoms Scale, PCS: Pain Catastrophizing Scale.

Table 6. Correlation between GPQ and the Other Questionnaires

\begin{tabular}{ccccc}
\hline GPQ score & & PSQ score & PASS score & PCS score \\
\hline Subgroup score & & & & $0.502^{\dagger}$ \\
Sensitivity & $\mathrm{r}$ & $0.296^{*}$ & $0.553^{\dagger}$ & $0.589^{\dagger}$ \\
Experience & $\mathrm{r}$ & $0.242^{*}$ & $0.625^{\dagger}$ & $0.627^{\dagger}$ \\
Other & $\mathrm{r}$ & $0.237^{*}$ & $0.587^{\dagger}$ & $0.621^{+}$ \\
Total score & $\mathrm{r}$ & $0.294^{*}$ & $0.647^{\dagger}$ &
\end{tabular}

r: Spearman's correlation coefficient, GPQ: Geop-Pain Questionnaire, PSQ: Pain Sensitivity Questionnaire, PASS: Pain Anxiety Symptoms Scale, PCS: Pain Catastrophizing Scale. ${ }^{*} \mathrm{P}<0.05,{ }^{\dagger} \mathrm{P}<0.001$.

Table 7. Linear Regression for Self-rating on Geop and Subjective Rating on the Relation of Geop and Pain

\begin{tabular}{|c|c|c|c|c|c|c|c|c|}
\hline \multirow{2}{*}{ Variables } & \multicolumn{4}{|c|}{ Self-rating on Geop } & \multicolumn{4}{|c|}{ Subjective rating on the relation of Geop and pain } \\
\hline & B & $(\mathrm{SE})$ & Beta & $\mathrm{P}$ & B & (SE) & Beta & $\mathrm{P}$ \\
\hline \multicolumn{9}{|c|}{ GPQ subgroup score } \\
\hline Sensitivity & 2.34 & $(0.50)$ & 11.61 & $<0.001$ & 1.46 & $(0.63)$ & 7.22 & 0.022 \\
\hline Experience & 2.32 & $(0.47)$ & 11.08 & $<0.001$ & 1.24 & $(0.60)$ & 5.92 & 0.043 \\
\hline Other & 1.87 & $(0.56)$ & 10.26 & 0.001 & 1.14 & $(0.68)$ & 6.29 & 0.095 \\
\hline Total score & 0.94 & $(0.19)$ & 1.74 & $<0.001$ & 0.55 & $(0.24)$ & 1.02 & 0.023 \\
\hline
\end{tabular}

Regression coefficients were calculated after adjustment by age, sex, experience of pain treatment. B: unstandardized regression coefficient, SE: standard error, Beta: Standardized regression coefficient, GPQ: Geop-Pain Questionnaire. 


\section{Discussion}

In the past decades, many studies have attempted to assess the level of a person's pain sensitivity using a multidimensional approach. To experimentally measure and evaluate the diversity of pain perception between individuals, stimulations with various properties, such as thermal, mechanical, ischemic, and electronic stimulations, have been used $[6,12,13]$. The experimental pain assessment methods, however, are limited by the equipment, time, and relevant cost, and most of all, may induce serious discomfort and pain in the individuals whose levels of pain sensitivity are being assessed. As such, practical methods that can replace the experimental assessment methods and can evaluate subjective experiences related to pain have been suggested. Among these methods are many self-rating questionnaires, and questionnaire surveys connecting various factors (e.g., fear, anxiety, sensitivity, catastrophizing, vigilance and awareness) with pain and grading them have been attempted $[4-8,14]$.

In the Eastern social and cultural environments, where people do not usually express themselves actively, self-rating questionnaires have not yet been widely used. In South Korea, selfrating questionnaires are clinically used primarily for academic purposes. One of the reasons for this is that it is not easy to find a pain-related questionnaire that was developed in South Korea. As for the MPQ, one of the few multidimensional pain questionnaires in use in South Korea, Diller [15] argued that if it were used in non-English-speaking areas, the words in the items could be interpreted differently from their dictionary definitions and might lose their original meanings. Kim et al. [16] stated that pain has various dimensions and that the expression of pain using one's native language is important; thus, they developed various pain terminology measurement cards in Korean. Additionally, using the concept of geop for the first time, by grading geop like the Numeric Rating Scale (NRS) and comparing its grade with the results obtained from the existing pain questionnaires, the authors reported that geop was statistically significantly correlated with pain [17]. They also mentioned, however, that their study was an exploratory study for identifying the tendency between geop and pain, and that further studies were required to make the NRS of geop one of the indicators of pain perception.

In this aspect, the first purpose of the current study was to develop a Geop-Pain questionnaire for the first time, with the goal of determining the level of a person's pain sensitivity by connecting the various meanings and conceptions of the Korean word geop with pain. Another important purpose of this study was to determine whether a change in the degree of pain felt by a patient could be predicted depending on the level of geop. In this study, it was most important to ensure that the participants' thoughts and feelings about geop were correctly and consistently reflected in the GPQ, expressed as specific sentences. Accordingly, to develop new questionnaire items instead of using the translated ones, before constructing the items, various thoughts on geop were researched, and based on the research results, efforts were made to ensure that the formulated questionnaire items could be easily and correctly understood, by using more familiar expressions. In the preliminary studies performed prior to the main study, the test-retest reliability was high in all the dimensions, showing that the respondents' consistent responses were well reflected (Tables 3 and 4).

In the main study, the GPQ was diversely compared with three pain-related questionnaires used after translation and certification, and because they showed strong correlations, the potential of the GPQ as a new questionnaire could be confirmed. However, the FOPQ [9] being used in studies for questionnaire development in the dentistry and traditional-Korean-medicine areas (mainly acupuncture), with very similar pain treatments, exploring the idea that the anxiety and fear felt before the treatment might affect the degree of pain felt after the treatment, was not included in this study because the validity of the FOPQ has not been proven in South Korea. It is believed, however, that it is necessary to compare this questionnaire with the GPQ in the future.

The current study intended to develop a Geop-Pain questionnaire that maximally reflects the components of the existing pain-related questionnaires based on the definition of "pain". For this reason, the questionnaire was divided into three subdimensions, and not only the GPQ as a whole but also the subdimensions of the GPQ were compared with the existing questionnaires. The difference in actual feelings or sensitivity, one of the indicators of diversity between individuals, may cause a change in geop and pain. Ruscheweyh et al. [6,7] stated that a great difference in the level of pain sensitivity was shown between individuals, and that pain sensitivity could be a risk factor progressing to chronic-pain disease; thus, its assessment is very important. Moreover, as a useful method of measuring an individual's pain sensitivity, the authors developed the PSQ, a selfrating questionnaire examining the intensity of pain expected to be felt when certain body parts are injured, by assuming various pain situations that may occur in everyday life.

In this study, GPQ items 1 to 5 were intended to reflect sense-related geop, and its correlation with the PSQ emphasizing the sensory parts explaining pain sensitivity was analyzed. Among the subdimensions of the GPQ, the sense dimension was confirmed to show the strongest correlation with the PSQ. Meanwhile, in cases when a person has undergone a painful and fearful experience such as receiving root canal treatment at a dental clinic, at the next treatment, the geop increases, and for the same treatment, the person feels more pain, and the pain can further increase. Conversely, if a person has a vague fear of pain, 
after going through an adaptation process or after directly experiencing the pain, the fear is eliminated, and the person may feel less pain at the next treatment [18].

For the PASS, which consists of 40 items in the four dimensions of cognitive factor, escape/avoidance factor, fear factor, and physiological anxiety, the stability, reliability, and convenience of the questionnaire have been verified in clinical practice and in the research field, among many methods measuring anxiety by associating it with pain, and it is widely used [19]. The PASS-20 is a short form of the PASS, with 40 items [8]. To reflect avoidance or a cognitive change, or anxiety through experience, items 6 to 10 in the GPQ were related to experience, and the correlation with the PASS-20 was analyzed. The PASS-20 revealed strong positive correlations with all dimensions of the GPQ and the total score on the GPQ, and the experience dimension of the GPQ had the strongest correlation with the PASS-20 (Table 6).

Lastly, items 11 to 15 in the GPQ were regarding exaggeration, catastrophizing, and socioeconomic factors, and reflected Geop-Pain association. Catastrophizing, conceptualized by Rosenstiel and Keefe [20], means that the negative cognitions of noxious stimuli are amplified, and as the negative aspects of the pain situation are focused on too much or are worried about, a person expects only negative results and consequently develops a feeling of helplessness, to the extent that he or she is unable to cope with the pain. The PCS was developed in 1995 by Sullivan et al. [5] to assess the degree of catastrophic thinking with regard to pain, and they stated that catastrophizing is an important psychological construct evaluating a person's thoughts and feelings when he or she is in pain, and adjusting the person's behavioral responses to pain. Moreover, Sullivan et al. [21] defined catastrophizing as an exaggerated negative feeling imposed while actual or expected pain experiences appear. The PCS consists of subscales, including rumination, magnification, and helplessness, and is widely used in assessing pain-related catastrophizing. The PCS is currently in use in South Korea as its translation and certification have been completed [22]. Items 11 to 15 in the GPQ were intended to reflect catastrophizing, and the external factors showed the strongest correlation with the PCS among all dimensions of the GPQ (Table 6). On the other hand, in the comparisons of the total GPQ score and the total scores in the other questionnaires, the PASS-20 and the PCS were found to have stronger correlations with the GPQ compared to the PSQ. The present study showed that the total GPQ score and the subdimensions were highly associated with the existing three questionnaires. In particular, as intended when developing the questionnaire, between the sense dimension of the GPQ and the PSQ, the experience dimension and the PASS-20, and the catastrophizing and external dimension and the PCS, there were strong correlations, which means that the GPQ has potential to become a new pain-related questionnaire that can be applied to clinical practice.

To examine the second purpose of this study, the influence of the level of geop on pain, the associations of the self-rated geop and Geop-Pain association with each dimension of the GPQ and the total GPQ score were analyzed (Table 7). The level of geop was significantly associated with the GPQ scores, and the Geop-Pain association score for investigating the participant's perception of Geop-Pain association was also significantly associated with the subdimensions of the GPQ and the total GPQ score. That is, the study participants thought that if they had more geop, they would feel more pain. In this study, however, the number of participants in their 20s was greater than the number of participants in the other age groups, and in terms of sex, there were slightly more females than males, which could pose a problem in generalizing the study results.

The simple dictionary meaning of geop may sound somewhat different from that of stress, but thinking in relation to pain, geop can be assumed to act as a stressor to patients. The influence of stress on pain has been reported in many studies, and the results were revealed in two different patterns. In an animal experiment using mice, Quintero et al. [23] explained that due to the reduction and delay of gamma-aminobutyric acid inhibitory control, which is involved in the activation of the postsynaptic N-methyl-D-aspartic acid receptor, pain hypersensitivity occurred due to stress. Martenson et al. [24] argued that as in their study, the pain-inducing neurons were activated by the activation of stress-related circuits located in the hypothalamus, and pain sensitivity occurred. Donello et al. [25] mentioned that in an experimental study in which repetitive stress stimuli were given, pain sensitivity was caused by the sympathetic nervous system in association with peripheral adrenergic receptors.

Contrary to the aforementioned claims, however, Carrive et al. [26] have also reported that repetitive stress reduced pain. If a person persistently experiences stress due to pain, the pain will be reduced due to the adaptation process and to the increase of the pain threshold. These contradictory results seem to be due to the fact that the influence of the emotional elements on pain has a complex and multidimensional structure. In the case of the initial experience or occurrence of anxiety or fear, when there are repetitive stimulations, the pain is reduced, but individuals experiencing unresolved persistent anxiety become more sensitive to pain [18]. Additionally, as in the results of a study in which the pain thresholds due to a noise stimulus were compared between males and females, within the same environments, different results may be generated depending on the sex, age, and various other factors of the study subjects [27].

Thus, the level of a patient's pain sensitivity can be predicted by conducting a pre-assessment, such as with the GPQ, before performing surgery or a procedure, and if the factors increasing pain sensitivity and stress can be eliminated, the GPQ can be 
a useful instrument for reducing pain. In recent years, with regard to the prediction of postoperative pain, many studies have reported that a patient's postoperative pain can be reduced by predicting the risk factors related to pain, which differ from one person to another, before surgery. Werner et al. [28] reported that the degree of pain perception of a preoperative patient was correlated with the degree of the patient's postoperative pain in experimental methods using pain stimuli. Additionally, in another study targeting 85 pregnant women scheduled to undergo cesarean section, the pregnant women who received a sufficient explanation of the procedure they were to undergo from an anesthetist before the surgery, and who were emotionally supported by their spouses, became less anxious, obtained greater postoperative satisfaction, and recovered rapidly [29]. Although it is not a predictor of pain, distraction, which reduces pain by decreasing the sensory and psychological factors, has also received attention. In children and adolescents, who may feel more pain than that which is actually produced by the stimulation that they receive due to their severe anxiety and fear of injection, the use of distraction, which disperses and offsets the psychological factors, can reduce the occurrence of pain [30]. The limitations of the current study include the small sample size and the fact that the experimental methods were not used together.
Therefore, further studies targeting more diverse age groups or various patient groups, such as patients waiting for surgery or dental or patients receiving pain treatment, will be conducted, with a larger sample size. Additionally, based on the results obtained from this survey, as reported by Rhudy et al. [12,27] or Ruscheweyh et al. [6,7], diverse additional investigations regarding pain perception by individuals are necessary, through the analysis of the associations between self-rating questionnaires and experimental methods performing experiments using cold, heat, noise, and electronic stimulations.

In conclusion, to predict complex pain in multidimensional aspects, a self-rating questionnaire that is easy to understand and that well reflects the condition of the patient must be formulated. As such, this study first attempted to develop a new questionnaire using the Korean word geop instead of using translated questionnaires. As a result, the potential of the newly developed questionnaire for use as a pain prediction index in clinical practice was demonstrated as it showed high correlations with the existing questionnaires. Moreover, it was revealed that if the study subjects had more geop, they believed that they would feel more pain, and it was confirmed that the level of geop could be used as a predictor of pain.

\section{References}

1. Merskey H, Bogduk N. Classification of Chronic Pain. 2nd ed. Seattle, IASP Press. 1994, pp 209-14.

2. Dionne RA, Bartoshuk L, Mogil J, Witter J. Individual responder analyses for pain: does one pain scale fit all? Trends Pharmacol Sci 2005; 26: $125-30$.

3. Fillingim RB. Individual differences in pain responses. Curr Rheumatol Rep 2005; 7: 342-7.

4. McNeil DW, Rainwater AJ 3rd. Development of the Fear of Pain Questionnaire--III. J Behav Med 1998; 21: 389-410.

5. Sullivan MJ, Bishop SR, Pivik J. The pain catastrophizing scale: development and validation. Psychol Assess 1995; 7: 524-32.

6. Ruscheweyh R, Marziniak M, Stumpenhorst F, Reinholz J, Knecht S. Pain sensitivity can be assessed by self-rating: development and validation of the Pain Sensitivity Questionnaire. Pain 2009; 146: 65-74.

7. Ruscheweyh R, Verneuer B, Dany K, Marziniak M, Wolowski A, Colak-Ekici R, et al. Validation of the pain sensitivity questionnaire in chronic pain patients. Pain 2012; 153: 1210-8.

8. McCracken LM, Dhingra L. A short version of the Pain Anxiety Symptoms Scale (PASS-20): preliminary development and validity. Pain Res Manag 2002; 7: 45-50.

9. Simons LE, Sieberg CB, Carpino E, Logan D, Berde C. The Fear of Pain Questionnaire (FOPQ): assessment of pain-related fear among children and adolescents with chronic pain. J Pain 2011; 12: 677-86.

10. Hobara M. Beliefs about appropriate pain behavior: cross-cultural and sex differences between Japanese and Euro-Americans. Eur J Pain 2005; 9: 389-93.

11. Kim HJ, Ruscheweyh R, Yeo JH, Cho HG, Yi JM, Chang BS, et al. Translation, cross-cultural adaptation, and validity of the Korean version of the pain sensitivity questionnaire in chronic pain patients. Pain Pract 2014; 14: 745-51.

12. Rhudy JL, Grimes JS, Meagher MW. Fear-induced hypoalgesia in humans: effects on low intensity thermal stimulation and finger temperature. J Pain 2004; 5: 458-68.

13. Werner MU, Mjöbo HN, Nielsen PR, Rudin A. Prediction of postoperative pain: a systematic review of predictive experimental pain studies. Anesthesiology 2010; 112: 1494-502.

14. Roelofs J, Peters ML, McCracken L, Vlaeyen JW. The pain vigilance and awareness questionnaire (PVAQ): further psychometric evaluation in fibromyalgia and other chronic pain syndromes. Pain 2003; 101: 299-306.

15. Diller A. Cross-cultural pain semantics. Pain 1980; 9: 9-26. 
16. Kim YI, Kang HC, Jung SH, Hwang KH, Ahn KR, Park W. The development of a Korean pain assessment Card. J Korean Pain Soc 2003; 16: $145-56$.

17. Koo BS, Jung MJ, Lee JH, Jin HC, Lee JS, Kim YI. A pilot study of the correlation between the numeric rating scale used to evaluate "Geop" and questionnaires on pain perception. Korean J Pain 2015; 28: 32-8.

18. Rhudy JL, Meagher MW. Fear and anxiety: divergent effects on human pain thresholds. Pain 2000; 84: 65-75.

19. McCracken LM, Zayfert C, Gross RT. The Pain Anxiety Symptoms Scale: development and validation of a scale to measure fear of pain. Pain 1992; 50: 67-73.

20. Rosenstiel AK, Keefe FJ. The use of coping strategies in chronic low back pain patients: relationship to patient characteristics and current adjustment. Pain 1983; 17: 33-44.

21. Sullivan MJ, Thorn B, Haythornthwaite JA, Keefe F, Martin M, Bradley LA, et al. Theoretical perspectives on the relation between catastrophizing and pain. Clin J Pain 2001; 17: 52-64.

22. Cho S, Kim HY, Lee JH. Validation of the Korean version of the Pain Catastrophizing Scale in patients with chronic non-cancer pain. Qual Life Res 2013; 22: 1767-72.

23. Quintero L, Cardenas R, Suarez-Roca H. Stress-induced hyperalgesia is associated with a reduced and delayed GABA inhibitory control that enhances post-synaptic NMDA receptor activation in the spinal cord. Pain 2011; 152: 1909-22.

24. Martenson ME, Cetas JS, Heinricher MM. A possible neural basis for stress-induced hyperalgesia. Pain 2009; 142: 236-44.

25. Donello JE, Guan Y, Tian M, Cheevers CV, Alcantara M, Cabrera S, et al. A peripheral adrenoceptor-mediated sympathetic mechanism can transform stress-induced analgesia into hyperalgesia. Anesthesiology 2011; 114: 1403-16.

26. Carrive P, Churyukanov M, Le Bars D. A reassessment of stress-induced "analgesia" in the rat using an unbiased method. Pain 2011; 152: 676-86.

27. Rhudy JL, Meagher MW. Noise stress and human pain thresholds: divergent effects in men and women. J Pain 2001; 2: 57-64.

28. Werner MU, Mjöbo HN, Nielsen PR, Rudin A. Prediction of postoperative pain: a systematic review of predictive experimental pain studies. Anesthesiology 2010; 112: 1494-502.

29. Hobson JA, Slade P, Wrench IJ, Power L. Preoperative anxiety and postoperative satisfaction in women undergoing elective caesarean section. Int J Obstet Anesth 2006; 15: 18-23.

30. Birnie KA, Noel M, Parker JA, Chambers CT, Uman LS, Kisely SR, et al. Systematic review and meta-analysis of distraction and hypnosis for needle-related pain and distress in children and adolescents. J Pediatr Psychol 2014; 39: 783-808. 


\section{Appendix 1.Geop-Pain Questionnaire}

\section{Geop-Pain Questionnaire (GPQ)}

* Please write the score that you think is appropriate on the blank provided after reading each item.

1. My skin is sensitive, and I am scared (have geop) if I feel more pain than other people do during a treatment.
Not at all (1)
A little (2)
Average (3)
Severe (4)
Very severe (5)
points

2. I am sensitive to ambient sound or noise, and I think I feel more pain during a treatment due to fear (geop) caused

by various sounds, such as other patients' moans or the alarm of the equipment in the treatment room.
Not at all (1)
A little (2)
Average (3)
Severe (4)
Very severe (5)

points

3. I think I feel more pain due to fear (geop) caused by a doctor (gown), a syringe, or the smell of disinfectant in the treatment room.
Not at all (1)
A little (2)
Average (3)
Severe (4)
Very severe (5)
points

4. I am scared (have geop) if I feel more pain during treatment because I do not well tolerate the cold or heat, and I am sensitive.
Not at all (1)
A little (2)
Average (3)
Severe (4)
Very severe (5)
points

5. I have an unusual constitution (e.g., easily getting a bruise or swelling, etc.) and I am more anxious and scared (have geop)

if I feel more pain or have complications.
Not at all (1)
A little (2)
Average (3)
Severe (4)
Very severe (5)

points

6. I am easily frightened (have a lot of geop) so I don't like trying out rides or seeing horror movies, but I cannot avoid pain treatment so I am very anxious and I think I feel more pain.
Not at all (1)
A little (2)
Average (3)
Severe (4)
Very severe (5)
points

7. I am usually very sensitive to stress, and due to the stress-to-pain treatment that I received, I think I feel more pain during the treatment. $\begin{array}{llll}\text { Not at all (1) } & \text { A little (2) } & \text { Average (3) } & \text { Severe (4) }\end{array}$ points

8. As I usually cannot stand pain very much, I am scared (feel geop) if I don't obtain treatment immediately or if rapid action is not taken, such as drug (painkiller) administration, when I have pain.
Not at all (1)
A little (2)
Average (3)
Severe (4)
Very severe (5)

points

9. I am afraid (have geop) if I feel severe pain again because it was difficult for me to tolerate the discomfort and pain that

I felt during treatment for mild burns or bruises or at another endoscopic treatment in the past.

$$
\begin{array}{lllll}
\text { Not at all (1) } & \text { A little (2) } & \text { Average (3) } & \text { Severe (4) } & \text { Very severe (5) }
\end{array}
$$

points

10. I am scared (feel geop) because I have had experiences of hearing negative stories about pain treatment from the TV, newspapers, or acquaintances, and I think I feel more pain during treatment.
Not at all (1)
A little (2)
Average (3)
Severe (4)
Very severe (5)

points

11. I am scared (have geop) due to my concerns about pain after treatment because I usually have a lot on my mind and I am imaginative, and I think I feel more pain.
Not at all (1)
A little (2)
Average (3)
Severe (4)
Very severe (5)

points

12. I am very anxious and scared (feel geop) because pain treatment seems to be repeated over a long time, and if I may not recover after treatment and may be abandoned and become isolated from the people around me.
Not at all (1)
A little (2)
Average (3)
Severe (4)
Very severe (5)

points

13. I am very timid (have a lot of geop) so if I can reduce pain, I don't hesitate to get very expensive treatment.

$$
\begin{array}{lllll}
\text { Not at all (1) } & \text { A little (2) } & \text { Average (3) } & \text { Severe (4) }
\end{array}
$$

points

14. I am scared (feel geop) because doctors seem to choose painful and irritating injections or endodontic treatment unilaterally instead of drug treatment or physical treatment not causing pain.
Not at all (1)
A little (2)
Average (3)
Severe (4)
Very severe (5)
points

15. I am anxious (feel geop) because doctors or nurses do not seem to precisely and kindly explain the situations before and after treatment, and I think I feel more pain due to this.
Not at all (1)
A little (2)
Average (3)
Severe (4)
Very severe (5)

points 


\section{겁-통증 설문지 (Geop-related Pain Questionnaire, GPQ)}

* 각 문항을 읽고 생각하는 점수를 적어주세요.

1. 나는 피부감각이 예민하여 치료시 다른 사람보다 통증을 더 많이 느낄 것 같아 겁이 난다.
1점) 전혀 아니다
2점) 조금 그렇다
3점) 보통이다
4점) 심한편이다
5점) 매우 심하다 점

2. 나는 주변 소리나 소음에 예민하여 다른 환자의 신음소리나, 치료실 안의 장비에서 들리는 알람 같은 다양한 소리 때문에 겁이 나서 치료시 통증을 더 많이 느낄 것 같다.
1점) 전혀 아니다
2점) 조금 그렇다 3 점) 보통이다
4점) 심한편이다
5점) 매우 심하다

3. 나는 치료실 안에서 의사(가운), 주사기, 소독약 냄새 때문에 겁이 나서 치료시 통증을 더 많이 느낄 것 같다.
1점) 전혀 아니다
2점) 조금 그렇다
3점) 보통이다
4점) 심한편이다
5점) 매우 심하다

4. 나는 추위나 더위를 잘 참지 못하고 예민하기 때문에 치료시 통증을 더 느낄 것 같아 겁이 난다.
1점) 전혀 아니다
2점) 조금 그렇다
3점) 보통이다
4점) 심한편이다
5점) 매우 심하다

5. 나는 특이한 체질이므로(예: 멍이 잘생기거나, 잘 붓거나 등) 이것 때문에 더 불안하고 통증을 더 많이 느끼거나 합병증이 생길 것 같아 겁이 난다.
1점) 전혀 아니다
2점) 조금 그렇다
3점) 보통이다
4점) 심한편이다
5점) 매우 심하다

6. 나는 겁이 많아서 평소 놀이기구 시승이나 공포영화 관람조차 싫어하고 피하는데 통증치료는 피할 수 없어서 매우 불안하고 통증을 더 많이 느낄 것 같다.
1점) 전혀 아니다
2점) 조금 그렇다
3점) 보통이다
4점) 심한편이다
5점) 매우 심하다

7. 나는 평소 스트레스에 매우 예민하여 통증 치료에 대한 스트레스로 인해 치료시 통증을 더 많이 느낄 것 같다.
1점) 전혀 아니다
2점) 조금 그렇다
3점) 보통이다
4점) 심한편이다
5점) 매우 심하다

8. 나는 평소에도 통증을 잘 참지 못하기 때문에 통증이 있을 때는 바로 치료를 받거나 약물(진통제) 투여 같은 빠른 조치를 하지 않으면 겁이 난다.
1점) 전혀 아니다
2점) 조금 그렇다
3점) 보통이다
4점) 심한편이다
5점) 매우 심하다

9. 나는 과거에도 경미한 화상이나 타박상 또는 다른 내시경 시술시 불편감과 통증을 참기 힘들었기 때문에 이번에도 심한 통증을 느낄 것 같아 겁이 난다.
1점) 전혀 아니다
2점) 조금 그렇다
3점) 보통이다
4점) 심한편이다
5점) 매우 심하다

10. 통증치료에 대해 방송이나 신문 또는 주변 지인들을 통해 얻어진 부정적인 이야기를 들어본 경험이 있어서 겁이 나고 치료시 통증을 더 느낄 것 같다.
1점) 전혀 아니다
2점) 조금 그렇다
3점) 보통이다
4점) 심한편이다
5점) 매우 심하다

11. 나는 평소 생각이 많고 상상력이 풍부하여 치료 전부터 치료 후의 통증 걱정에 겁이 나고 통증도 더 많이 느낄 것 같다.
1점) 전혀 아니다
2점) 조금 그렇다
3점) 보통이다
4점) 심한편이다
5점) 매우 심하다

12. 나는 통증치료가 장기간 반복될 것 같고 치료 받은 후에도 회복되지 않아 주변사람들로부터 버림받고 소외될 것 같은 생각에 매우 불안하고 겁이 난다.
1점) 전혀 아니다
2점) 조금 그렇다
3점) 보통이다
4점) 심한편이다
5점) 매우 심하다

점

13. 나는 통증을 줄일 수 있다면 높은 비용의 치료도 주저하지 않을 정도로 겁이 많다.

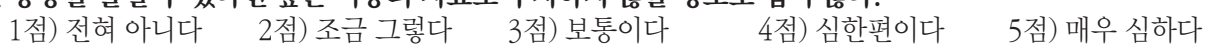

14. 나는 의사가 통증이 유발되지 않는 약물치료나 물리치료 대신, 아프고 자극적인 주사나 신경치료를 일방적으로 선택 하는 것 같아 겁이 난다.
1점) 전혀 아니다
2점) 조금 그렇다
3점) 보통이다
4점) 심한편이다
5점) 매우 심하다

점

15. 나는 의사나 간호사가 치료 전과 후 상황에 대해 상세하고 친절한 설명을 해주지 않는 것 같아 불안하며 이것 때문에 통증을 더 많이 느낄 것 같다.
1점) 전혀 아니다
2점) 조금 그렇다
3점) 보통이다
4점) 심한편이다
5점) 매우 심하다

점

총 점: 점 
Appendix 2. Survey of Geop Score and Geop-Pain Scale

$<$ English Translation Version $>$

\section{General Measurement of Geop}

Sex: $\underline{M / F} \quad$ Age: ___ Experience of Pain Treatment: $\underline{\text { Yes / No }}$

- Do you know the meaning of the word geop?

$\underline{\text { Yes / No }}$

- Do you have a lot of geop or only a little geop? Please express the level of geop that you think you have in numbers.

A lot of geop $100<------------>0 \quad$ No geop at all points

- Do you think that if you have more geop, you feel more pain than others do? (Or do you think that if you do not have geop, you feel less pain than others do?)

Strongly agree $100<------------>0 \quad$ Not at all points

- Time required for accomplishing the questionnaire: minutes

- Understanding of questionnaire items:

Very easy to understand $100<------------>0 \quad$ Cannot be understood at all points 
$<$ Korean Original Version $>$

겁에 대한 일반적 측정

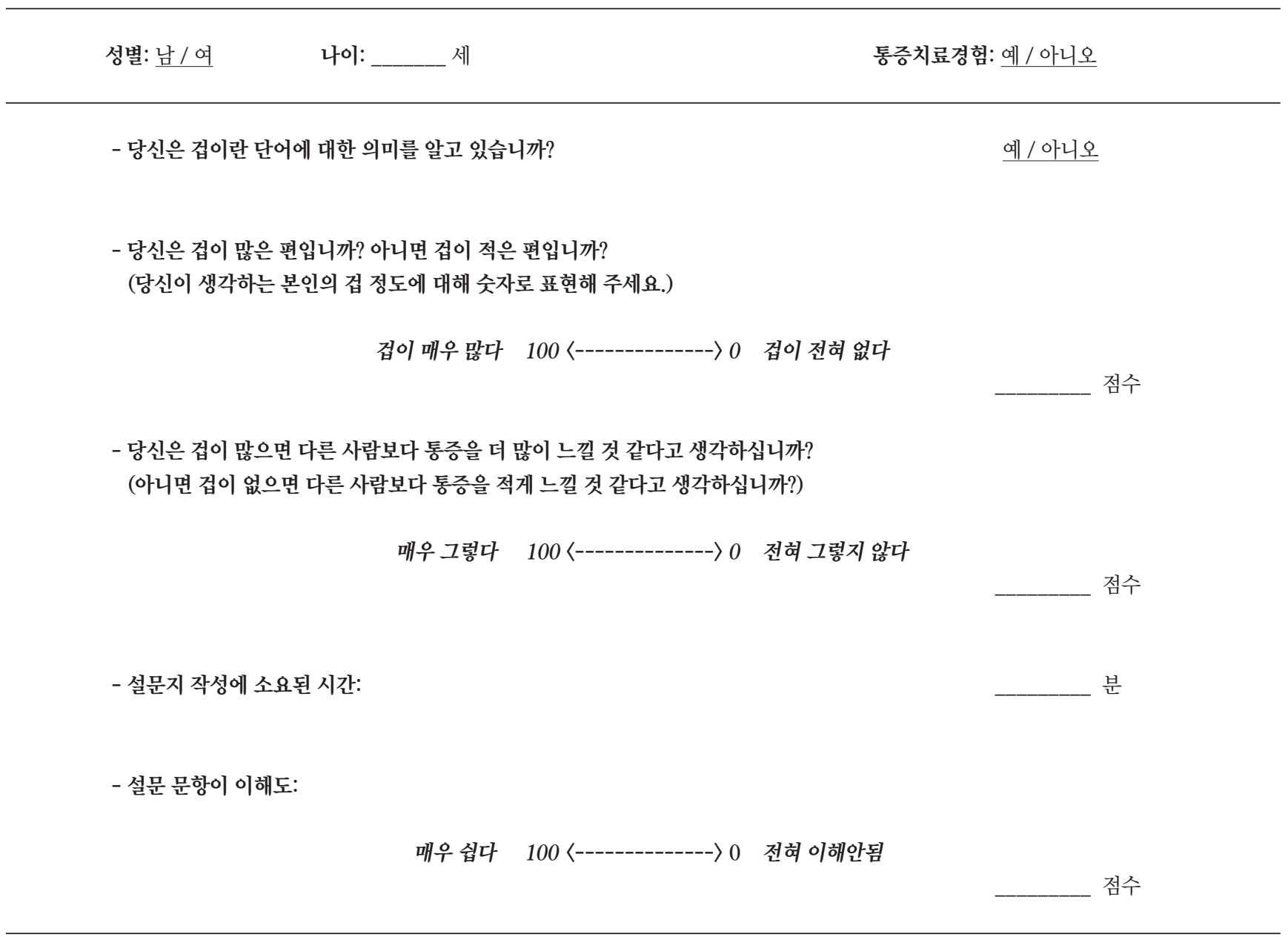

